\title{
Comparison of Root System Morphology of Cucurbit Rootstocks for Use in Watermelon Grafting
}

\author{
Matthew B. Bertucci ${ }^{1,4}$, David H. Suchoff ${ }^{2}$, Katherine M. Jennings ${ }^{3}$, \\ David W. Monks ${ }^{3}$, Christopher C. Gunter ${ }^{3}$, \\ Jonathan R. Schultheis ${ }^{3}$, and Frank J. Louws ${ }^{3}$
}

AdDitional INDEX wORDs. Citrullus lanatus, Cucurbita maxima, Cucurbita moschata, Cucurbita pepo, Lagenaria siceraria, scion

SUMMARY. Grafting of watermelon (Citrullus lanatus) is an established production practice that provides resistance to soilborne diseases or tolerance to abiotic stresses. Watermelon may be grafted on several cucurbit species (interspecific grafting); however, little research exists to describe root systems of these diverse rootstocks. A greenhouse study was conducted to compare root system morphology of nine commercially available cucurbit rootstocks, representing four species: pumpkin (Cucurbita maxima), squash (Cucurbita pepo), bottle gourd (Lagenaria siceraria), and an interspecific hybrid squash (C. maxima $\times$ C. moschata). Rootstocks were grafted with a triploid watermelon scion ('Exclamation'), and root systems were compared with nongrafted (NG) and self-grafted (SG) 'Exclamation'. Plants were harvested destructively at 1,2 , and 3 weeks after transplant (WAT), and data were collected on scion dry weight, total root length (TRL), average root diameter, root surface area, root:shoot dry-weight ratio, root diameter class proportions, and specific root length. For all response variables, the main effect of rootstock and rootstock species was significant $(P<0.05)$. The main effect of harvest was significant $(P<0.05)$ for all response variables, with the exception of TRL proportion in diameter class 2 . 'Ferro' rootstock produced the largest TRL and root surface area, with observed values $122 \%$ and $120 \%$ greater than the smallest root system ('Exclamation' SG), respectively. Among rootstock species, pumpkin produced the largest TRL and root surface area, with observed values $100 \%$ and $82 \%$ greater than those of watermelon, respectively. These results demonstrate that substantial differences exist during the initial 3 WAT in root system morphology of rootstocks and rootstock species available for watermelon grafting and that morphologic differences of root systems can be characterized using image analysis.

G rafting of cucurbitaceous and solanaceous crops has become an established integrated pest management tool for the management of soilborne pathogens. The effectiveness of grafting

This research was supported by the National Institute of Food and Agriculture, U.S. Department of Agriculture, under award no. 2011-01397.

We thank Dr. Ricardo Hernandez and Cristian Collado for sharing resources and expertise to help execute the study. We thank the USDA-NIFA-2011-51181-30963 for providing funding for this research and also thank North Carolina State University and North Carolina Department of Agriculture and Consumer Services for supporting this research. Last, we are grateful for the watermelon and rootstock seeds, which were generously donated by each company.

${ }^{1}$ Department of Crop, Soil, and Environmental Sciences, University of Arkansas, Fayetteville, AR 72704

${ }^{2}$ Department of Crop and Soil Sciences, North Carolina State University, Raleigh, NC 27695

${ }^{3}$ Department of Horticultural Science, North Carolina State University, Raleigh, NC 27695

${ }^{4}$ Corresponding author. E-mail: bertucci@uark.edu.

https://doi.org/10.21273/HORTTECH04098-18 for management of diseases relies on rootstocks that are either nonhost resistant or contain resistance genes for specific soilborne pathogens (Louws et al., 2010). Although the initial and main impetus for using grafted plants has been the ability to grow crops in fields that would otherwise be unsuitable as a result of disease pressure from soilborne pathogens
(Lee and Oda, 2003), additional rootstock-derived benefits have been demonstrated.

Rootstock-imparted abiotic stress tolerance has been reviewed extensively (Rouphael et al., 2017; Schwarz et al., 2010). In cucurbit crops, certain rootstocks can improve growth and yield at suboptimal soil temperatures (Ahn et al., 1999; Zhou et al., 2007), reduced irrigation (Rouphael et al., 2008), and salinity (Colla et al., 2006; Huang et al., 2010). Research has focused on cucurbit rootstock root system physiology to help explain this improved tolerance; however, research has only been conducted with figleaf gourd (Cucurbita ficifolia) and is limited to suboptimal soil temperatures (Lee et al., 2005a, 2005b). Although root physiology is important for the maintenance of growth under limiting conditions, morphology should also be considered when investigating soil resource acquisition.

Substantial research has been conducted exploring root system morphology as it relates to resource uptake and use efficiency. Root morphologic and architectural traits such as diameter, length, and spatial distribution all affect water uptake (Comas et al., 2013; Ho et al., 2005; Mickelbart et al., 2015), phosphorus uptake (Hill et al., 2006; Zobel et al., 2007), and salinity tolerance (Lovelli et al., 2012). To date, little research has been conducted to compare cucurbit rootstock root systems. A survey of tomato (Solanum lycopersicum) rootstock root systems was conducted and showed that significant differences exist among commercially available rootstocks (Suchoff et al., 2017). Compared with tomato rootstocks, cucurbit rootstocks span a wider genetic range; in addition to exotic

\begin{tabular}{llll}
\hline $\begin{array}{l}\text { Units } \\
\begin{array}{l}\text { To convert U.S. to SI, } \\
\text { multiply by }\end{array}\end{array}$ & U.S. unit & Sl unit & $\begin{array}{l}\text { To convert SI to U.S., } \\
\text { multiply by }\end{array}$ \\
\hline 29,574 & $\mathrm{fl} \mathrm{oz}$ & $\mu \mathrm{L}$ & $3.3814 \times 10^{-5}$ \\
29.5735 & $\mathrm{fl} \mathrm{oz}$ & $\mathrm{mL}$ & 0.0338 \\
2.54 & inch $(\mathrm{es})$ & $\mathrm{cm}$ & 0.3937 \\
25.4 & inch $(\mathrm{es})$ & $\mathrm{mm}$ & 0.0394 \\
0.0896 & inch/oz & $\mathrm{cm} \cdot \mathrm{g}^{-1}$ & 11.1612 \\
6.4516 & inch & $\mathrm{cm}{ }^{2}$ & 0.1550 \\
28.3495 & $\mathrm{oz}$ & $\mathrm{g}$ & 0.0353 \\
7.4892 & $\mathrm{oz} / \mathrm{gal}^{2}$ & $\mathrm{~g} \cdot \mathrm{L}^{-1}$ & 0.1335 \\
1.7300 & $\mathrm{oz} / \mathrm{inch}^{3}$ & $\mathrm{~g} \cdot \mathrm{cm}^{-3}$ & 0.5780 \\
0.0069 & $\mathrm{psi}$ & $\mathrm{MPa}$ & 145.0377 \\
0.9464 & $\mathrm{qt}$ & $\mathrm{L}$ & 1.0567 \\
$\left({ }^{\circ} \mathrm{F}-32\right) \div 1.8$ & ${ }^{\circ} \mathrm{F}$ & ${ }^{\circ} \mathrm{C}$ & $\left({ }^{\circ} \mathrm{C} \times 1.8\right)+32$
\end{tabular}

Horllechnology · October $201828(5)$ 
watermelon germplasm (Cohen et al., 2014), common rootstocks for watermelon scions include interspecific hybrids, bottle gourd, squash, and pumpkin (Lee and Oda, 2003). As such, there exists the potential for significant variation among cucurbit rootstock root system morphologies, which may explain some of the improved growth under limiting conditions.

The objectives of the study were 1) to determine if differences exist in root system morphologies among SG 'Exclamation', NG 'Exclamation', and nine cucurbit rootstocks grown in a solid, soilless medium; and 2) to determine whether these root system morphologies change or remain similar during the initial 3 WAT.

\section{Materials and methods}

This study was conducted twice in a greenhouse at the Horticultural Field Laboratory at North Carolina State University between 23 Oct. 2016 and 29 Mar. 2017. The triploid seedless watermelon cultivar Exclamation (Syngenta Seeds, Greensboro, NC) was used as NG and SG controls as well as the scion for all rootstocks. Nine cucurbit rootstocks representing four species were used (Table 1). Scions were sown in 72 -cell planting trays (T.O. Plastics, Clearwater, $\mathrm{MN}$ ) filled with a presaturated soilless propagation mix (CC Tobacco Mix; Carolina Soil Co., Kinston, NC). All trays were placed on heating pads set to $89^{\circ} \mathrm{F}$ in a greenhouse adjusted to $84^{\circ} \mathrm{F}$. Triploid watermelon seed were sown with radicle facing upward to encourage shedding of the seedcoat after emergence (Maynard, 1989). Rootstocks were sown in a specialized propagation media composed of $2: 1 \mathrm{v} / \mathrm{v}$ mixture of calcined clay soil conditioner (Turface MVP; Profile Products, Buffalo Grove, IL) and silica sand (\#20 Pool Filter Sand; Aquabrite $^{\circledR}$, Pleasanton, CA) similar to previous root morphology studies (Manavalan et al., 2010; Suchoff et al., 2017). A l:1 v/v mixture of calcined clay soil conditioner and sand exhibited a reported bulk density of $1.22 \mathrm{~g} \cdot \mathrm{cm}^{-3}$, and gravimetric water content and volumetric water holding capacity (at saturation) of 0.50 and 0.61 , respectively (Petrie and Hall, 1992). A $2: 1 \mathrm{v} / \mathrm{v}$ mixture of the same components exhibited penetration resistance of 1.5 to $1.7 \mathrm{MPa}$ and was considered to cause no mechanical resistance, making it suitable as a substrate for observation of root development, while also facilitating thorough and efficient root harvesting (Manavalan et al., 2010; Suchoff et al., 2017). When grafting with multiple rootstock species, it is common practice to stagger sowing of rootstock seeds to synchronize rootstock emergence for grafting (Keinath and Hassell, 2014). Thus, rootstock germination tests were conducted to determine relative sowing to ensure all plants were the same size and growth stage at the time of grafting. Based on emergence timings, 'Exclamation' (which served as rootstock) was sown initially (day 0 ), followed by 'Emphasis', 'Kazako', 'Pelops', and 'Root Power' (day 6); and finally by 'BS1', 'Carnivor', 'Ferro', 'RS841', and 'TZ148' (day 7). 'Exclamation' for scions was sown early (day 3 ) to ensure hypocotyls of rootstocks and scions were the same size at the time of grafting. 'Exclamation' NG was sown later (day 12) than rootstocks and scions to account for delayed growth during the healing process of grafted plants.

Shortly after emergence, when cotyledons had turned upward and fully opened, rootstock apical meristems were treated with $25 \mu \mathrm{L}$ of a $6.25 \%$ dilution of a sucker control agent (Fair $85^{\circledR}$ fatty; Fair Products, Cary, NC). The sucker control agent effectively killed rootstock meristematic tissue, preventing rootstock regrowth after grafting (Daley and Hassell, 2014). Twenty-four hours before grafting, plants were placed indoors in a room with limited light and were adjusted to $68{ }^{\circ} \mathrm{F}$ to slow photosynthesis and metabolic activity. Grafting was conducted indoors using the one cotyledon method as described by Hassel et al. (2008). After grafting, plants were placed in a climate-controlled healing chamber made from transparent plastic storage bins $(26.5$ inches long $\times 16$ inches wide $\times 12.5$ inches wide; Sterilite ${ }^{\circledR}$, Townsend, MA). Water was added to a depth of $4 \mathrm{~cm}$ in each bin to maintain humidity, and flats were placed on a stand within the bins so as not to sit directly in the water. The plastic storage bins were placed in a controlled environment at $78.8^{\circ} \mathrm{F}$ beneath fluorescent grow lights, where they received $100 \mu \mathrm{mol} \cdot \mathrm{m}^{-2} \cdot \mathrm{s}^{-1}$ of photosynthetically active radiation. Lids were affixed with adhesive tape for the first $2 \mathrm{~d}$ after grafting (DAG). Lids were cracked open $3 \mathrm{DAG}$, offset to allow $50 \%$ exposure to ambient air (4 DAG), then completely removed (5-6 DAG). This process allowed for acclimation and hardening-off of the grafted plants. Plants were moved to the greenhouse 8 DAG.

All plants were transplanted into 3-qt black polyethylene pots (PolyTainer \#l; Hummert International, Earth City, MO) filled with the same $2: 1 \mathrm{v} / \mathrm{v}$ mixture of calcined clay and sand used for seedling propagation. Pots were lined with a mesh fabric to aid in root ball excavation. Plants were watered twice daily until water drained freely from containers and were fertilized weekly with $200 \mathrm{mg} \cdot \mathrm{L}^{-1}$ 20N-4.4P-16.6K (Peters Professional; JR Peters, Allentown, PA).

Experimental factors for this study were rootstocks (this includes NG and SG controls) and harvest time, which were 1,2 , or 3 WAT. The experiment followed a full factorial (1 l rootstocks $\times 3$ harvest times) randomized complete block design, with four blocks placed down the greenhouse bench to account for temperature gradients associated with proximity to the evaporative cooling wall.

Data collection. Complete excavation of root systems was necessary to characterize root system morphology. Thus, each experimental unit (a single plant) was harvested destructively at 1,2 , or 3 WAT, according to treatment. For scion data, grafted plants were cut at the graft union and scion fresh weight was collected. Scions were then placed in a dryer set to $70{ }^{\circ} \mathrm{C}$ for 72 to $96 \mathrm{~h}$, and scion dry weights were subsequently recorded. 'Exclamation' NG had no graft union, so plants were instead cut at the surface of the media and data were collected as described for grafted plants. Root systems were harvested from pots by carefully lifting the mesh fabric from each pot and placing the intact root system onto a flat surface for cleaning. Roots were excavated carefully from the media and submerged in water for further cleaning. Finally, the media and mesh fabric were checked thoroughly for broken roots that, when found, were added to the harvested root system. 
After cleaning, root systems were placed in $10 \mathrm{~mL} 0.5 \mathrm{~g} \cdot \mathrm{L}^{-1}$ neutral red stain (Sigma Aldrich, St. Louis, MO) and stored at $6.7^{\circ} \mathrm{C}$ for $24 \mathrm{~h}$. Dyed roots were rinsed with deionized (DI) water then scanned using a flatbed scanner (Expression 10000XL; Epson America, Long Beach, CA) with a $30 \times 42-\mathrm{cm}$ acrylic tray placed on top filled with $2 \mathrm{~cm}$ DI water. Root systems were positioned to minimize overlapping roots, and grayscale image resolution was set to 800 dots per inch to allow for high resolution of the finest roots. Images were analyzed using root system image analysis software (WinRHIZO version 2012b; Regent Instruments, Quebec, QC, Canada). Root morphologic data collected from these scans included TRL, average root diameter, diameter class length, diameter class length proportions, and total root surface area. TRL of root systems was partitioned into diameter class length - an important physiologic characteristic describing the fraction (by length) of a root system having a particular diameter. Diameter classes in this study were numbered 1 to 3 and included root diameters of less than $0.5,0.5$ to 1.0 , and more than $1.0 \mathrm{~mm}$, respectively. Diameter class proportions were calculated by dividing diameter class length by TRL. After scanning, root samples were placed in a dryer set to $70{ }^{\circ} \mathrm{C}$ for 72 to $96 \mathrm{~h}$ and were subsequently weighed. Specific root length (SRL; in centimeters per gram) measures root length per dry weight and was calculated by dividing TRL by dry root weight. And the root:shoot ratio was calculated by the dividing dry weight of the harvested root system with the dry weight of the scion.

Statistical analysis. Analysis of variance (ANOVA) was conducted using the GLIMMIX procedure in SAS (version 9.4; SAS Institute, Cary, NC). Rootstock, rootstock species, harvest, and the interactions of rootstock or rootstock species with harvest were treated as fixed effects. Trial and replicate nested within trial were specified as random effects. Diameter class length proportion data were analyzed using a beta distribution and logit transformation to account for the non-normal nature of proportional data. TRL and SRL data

Table 1. List of cultivars and seed sources for plant materials used as rootstocks and scions in greenhouse studies for comparison of root system morphology.

\begin{tabular}{llll}
\hline Cultivar & \multicolumn{1}{c}{ Species $^{\mathbf{z}}$} & \multicolumn{1}{c}{ Company } & \multicolumn{1}{c}{ Location } \\
\hline Exclamation & Watermelon & Syngenta Seeds & Greenville, NC \\
Root Power & Pumpkin & Sakata Seed America & Morgan Hill, CA \\
BS1 & Squash & Origene Seeds & Gehovot, Israel \\
Carnivor & Interspecific hybrid squash & Syngenta Seeds & De Lier, Netherlands \\
Ferro & Interspecific hybrid squash & Rijk Zwaan & Greenville, NC \\
Kazako & Interspecific hybrid squash & Syngenta Seeds & St. Louis, MO \\
RS841 & Interspecific hybrid squash & Seminis Vegetable Seeds & Modesto, CA \\
TZ148 & Interspecific hybrid squash & Harris Moran Seed Company & Greenville, NC \\
Emphasis & Bottle gourd & Syngenta Seeds & De Lier, Netherlands \\
Pelops & Bottle gourd & Rijk Zwaan &
\end{tabular}

${ }^{\mathrm{z}}$ Interspecific hybrid squash derived from the cross Cucurbita maxima $\times$ C. moschata.

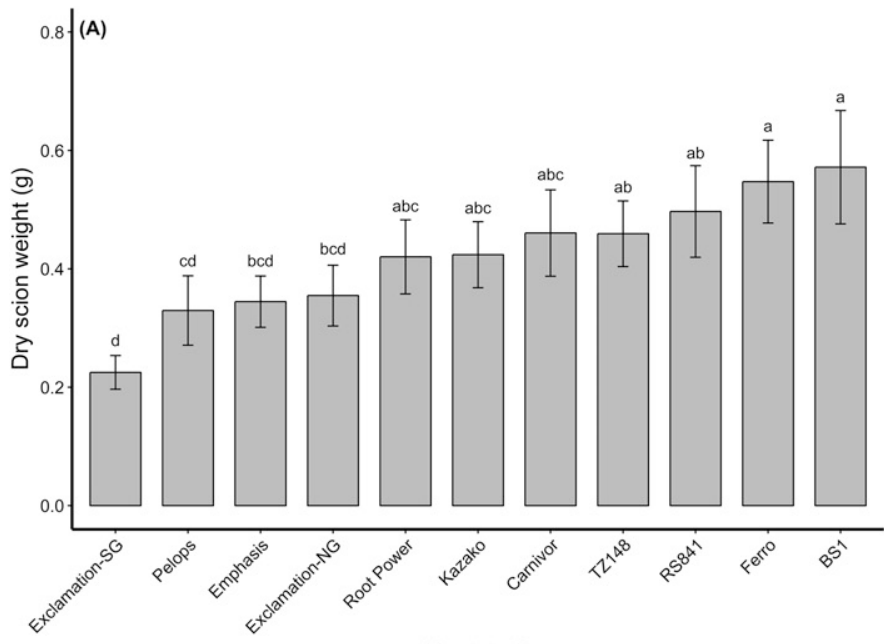

Rootstock
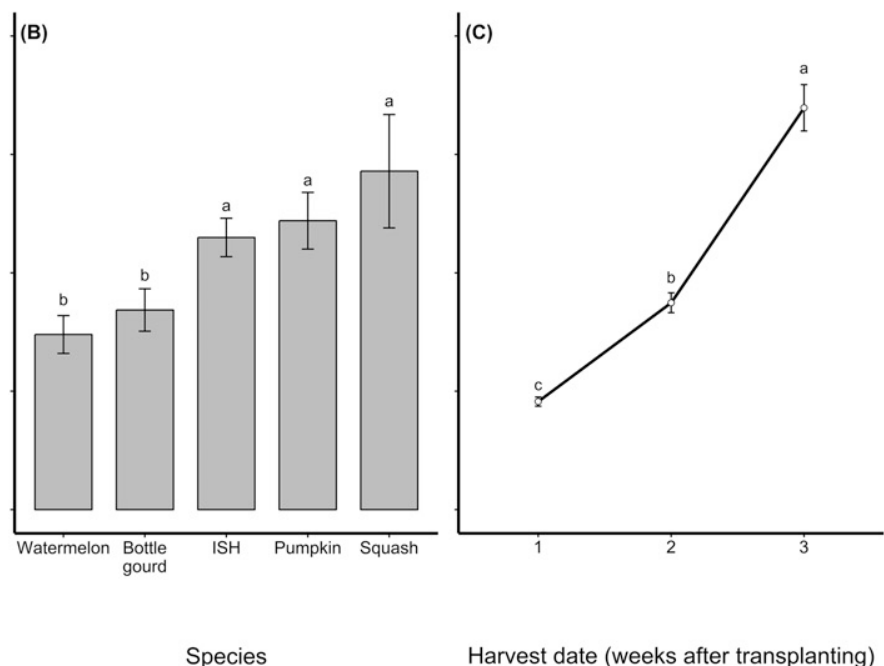

Fig. 1. Comparison of scion dry weight accumulation ( $\pm \mathrm{SE})$ as affected by (A) rootstock, (B) species, and (C) harvest date. 'Exclamation' watermelon was grafted to 10 cucurbit rootstocks and was used as a nongrafted control. All plants were grown in a greenhouse and harvested at 1,2 , and 3 weeks after transplanting. Scions were dried in an oven set to $70{ }^{\circ} \mathrm{C}\left(158.0{ }^{\circ} \mathrm{F}\right)$ for 72 to $96 \mathrm{~h}$, then weighed. Analysis of variance determined $P$ values were $<0.0001$ for rootstock, species, and harvest date; and no significant interactions were observed. Mean separation was achieved using the post hoc Tukey's honestly significant difference multiple comparisons adjustment. Means accompanied by the same letter did not differ at $\alpha=0.05$. SG, self-grafted; NG, nongrafted; ISH, interspecific hybrid squash derived from the cross Cucurbita maxima $\times$ C. moschata; $1 \mathrm{~g}=0.0353$ oz. 
showed strong heterogeneity of variance. To address this issue, these data were square root-transformed to normalize the distribution of residuals. These data were back-transformed for presentation in tables and figures. Any effect found to be significant $(P<0.05)$ was investigated further through mean separation using the post hoc Tukey's honestly significant difference (HSD) multiple comparisons adjustment.

\section{Results}

ANOVA of scion dry weight detected a significant effect of rootstock, species, and harvest, but no interaction of rootstock or species with harvest. Thus, least square means of each main effect were combined across all levels of the other factor (i.e., marginal means) and subjected to mean separation according to Tukey's HSD (Fig. 1). Scion dry weight accumulation was greatest in 'BSI' and 'Ferro' rootstocks, but means were not statistically different from 7 of 11 rootstock treatments (Fig. 1A). The lowest scion weight was produced by 'Exclamation' SG, which was similar statistically to ' $\mathrm{Ex}$ clamation' NG, 'Emphasis', and 'Pelops' rootstocks. Scion dry weight differed according to species, with the lowest dry weights observed in watermelon and bottle gourd rootstocks and the highest dry weights in interspecific hybrids, pumpkin, and squash rootstocks (Fig. 1B). As expected, scion dry weights increased as harvest was delayed. Compared with harvests at 1 WAT, scion dry weight of the final harvest ( 3 WAT) exhibited a 3.7-fold increase (from 0.18-0.68 g; Fig. 1C).

ANOVA of root system characteristics determined the main effects of rootstock, species, and harvest date were significant, and no significant interactions of rootstock or species with harvest existed. Thus, least square means for each main effect were subjected to mean separation according to Tukey's HSD (Tables 2 and 3). TRL was greatest in 'Ferro' rootstock; lowest TRL was observed in 'Pelops', 'Exclamation' NG, and 'Exclamation' SG. A substantial disparity existed between the largest and smallest TRL of rootstocks. Compared with 'Ferro' rootstock, the smaller root systems of 'Exclamation' NG, 'Pelops', and 'Exclamation' SG produced only $51 \%, 45 \%$, and $45 \%$ of the TRL, respectively. As expected, TRL increased over time, and TRL nearly doubled each week that harvest was delayed (Table 2). Largest average root diameters were observed in 'Emphasis', 'Exclamation' NG, and 'Pelops' (range, 0.15-0.16 mm), followed by seven rootstocks with intermediate (range, 0.11-0.12 mm) average root diameters and 'Kazako' with the smallest average root diameter $(0.9 \mathrm{~mm})$. Root surface area and ratios of root:shoot dry weight generally followed the same pattern of TRL, indicating that root systems with greater root length also had an increased root surface area and a greater proportion of biomass partitioned to roots rather than the scion.

When comparing rootstock species, pumpkin, squash, and interspecific hybrids exhibited the greatest TRL, greatest root surface area, and lowest average root diameter (Table 3 ). Bottle gourd and watermelon rootstocks

Table 2. Comparison of main effects of rootstock and harvest date on root system morphology characteristics of 11 cucurbit rootstocks with 'Exclamation' watermelon as the scion. Total root length, average root diameter, and root surface area were measured using intact harvested root systems and image analysis software (WinRHIZO version 2012b; Regent Instruments, Quebec, QC, Canada). Root weight-to-shoot weight ratios were calculated using the weight of dried root and shoot tissue of plants at each harvest date. ${ }^{\mathrm{z}}$

\begin{tabular}{|c|c|c|c|c|}
\hline Rootstock & $\begin{array}{c}\text { Total root } \\
\text { length }(\mathrm{cm})^{\mathrm{y}}\end{array}$ & $\begin{array}{c}\text { Avg root } \\
\operatorname{diam}(\mathbf{m m})^{y}\end{array}$ & $\begin{array}{l}\text { Root surface } \\
\text { area }\left(\mathrm{cm}^{2}\right)^{\mathrm{y}}\end{array}$ & $\begin{array}{l}\text { Root wt:shoot } \\
\text { wt (ratio) }\end{array}$ \\
\hline Ferro & $3,149 \mathrm{a}^{\mathrm{x}}$ & $0.13 \mathrm{~b}$ & $350 \mathrm{a}$ & $0.40 \mathrm{a}$ \\
\hline RS841 & $3,006 \mathrm{ab}$ & $0.11 \mathrm{~b}$ & $322 \mathrm{a}$ & $0.38 \mathrm{ab}$ \\
\hline TZ148 & $2,947 \mathrm{ab}$ & $0.11 \mathrm{~b}$ & $310 \mathrm{ab}$ & $0.39 \mathrm{a}$ \\
\hline BSI & $2,916 \mathrm{ab}$ & $0.12 \mathrm{~b}$ & $318 \mathrm{a}$ & $0.35 \mathrm{a}-\mathrm{d}$ \\
\hline Root Power & $2,872 \mathrm{ab}$ & $0.11 \mathrm{~b}$ & $297 \mathrm{ab}$ & $0.41 \mathrm{a}$ \\
\hline Carnivor & $2,572 \mathrm{ab}$ & $0.12 \mathrm{~b}$ & 276 a-d & $0.38 \mathrm{ab}$ \\
\hline Kazako & $2,287 \mathrm{bc}$ & $0.09 \mathrm{c}$ & $217 \mathrm{~d}-\mathrm{f}$ & $0.27 \mathrm{~d}$ \\
\hline Emphasis & $1,850 \mathrm{~cd}$ & $0.16 \mathrm{a}$ & $234 \mathrm{~b}-\mathrm{d}$ & $0.37 \mathrm{abc}$ \\
\hline Exclamation NG & $1,619 \mathrm{~d}$ & $0.16 \mathrm{a}$ & $200 \mathrm{def}$ & $0.28 \mathrm{~d}$ \\
\hline Pelops & $1,420 \mathrm{~d}$ & $0.15 \mathrm{a}$ & $174 \mathrm{ef}$ & $0.31 \mathrm{bcd}$ \\
\hline Exclamation SG & $1,413 \mathrm{~d}$ & $0.13 \mathrm{~b}$ & $159 \mathrm{f}$ & $0.29 \mathrm{~cd}$ \\
\hline \multicolumn{5}{|l|}{ Harvest } \\
\hline $1 \mathrm{WAT}$ & $979 \mathrm{c}$ & $0.12 \mathrm{~b}$ & $106 \mathrm{c}$ & $0.34 \mathrm{~b}$ \\
\hline $2 \mathrm{WAT}$ & $2,394 \mathrm{~b}$ & $0.13 \mathrm{a}$ & $274 \mathrm{~b}$ & $0.38 \mathrm{a}$ \\
\hline $3 \mathrm{WAT}$ & $4,047 \mathrm{a}$ & $0.12 \mathrm{~b}$ & $446 \mathrm{a}$ & $0.32 \mathrm{~b}$ \\
\hline \multicolumn{5}{|l|}{ Effect ( $P$ value $)$} \\
\hline Rootstock & $* * *$ & $* * *$ & $* * *$ & $* * *$ \\
\hline Harvest & $* * *$ & ** & $\star * *$ & $* * *$ \\
\hline Rootstock $\times$ harvest & NS & NS & NS & NS \\
\hline
\end{tabular}

${ }^{\mathrm{z}}$ To account for heterogeneity of variance, analysis of variance and mean separation were conducted using square root-transformed data for total root length, which were then back-transformed for presentation in this table.

${ }^{\mathrm{y}} 1 \mathrm{~cm}=0.3937$ inch, $1 \mathrm{~mm}=0.0394$ inch, $1 \mathrm{~cm}^{2}=0.1550$ inch $^{2}$.

${ }^{\mathrm{x}}$ Mean separation was achieved using the post hoc Tukey's honest significant difference multiple comparisons adjustment. Means followed by the same letter did not differ at $\alpha=0.05$. Rootstock, harvest, and rootstock $\times$ harvest had 10,2 , and $20 \mathrm{df}$, respectively.

$\mathrm{NS},{ }^{*},{ }^{* *},{ }^{* *}$ Nonsignificant or significant at $P \leq 0.05,0.01$, or 0.001 , respectively.

$\mathrm{NG}=$ nongrafted; $\mathrm{SG}=$ self-grafted; WAT $=$ week $(\mathrm{s})$ after transplanting. 
rootstocks, the majority of TRL fell within diameter class 1 (Table 4). Comparisons within diameter class 1 reveal that the greatest proportions were observed in 'Kazako' and 'Exclamation' SG, and the lowest proportions were observed in 'Emphasis', 'Pelops', 'Exclamation' NG, 'Ferro', 'BSl', and 'Carnivor'. The inverse is true of diameter class 2; 'Kazako' and 'Exclamation' SG produced the lowest proportions of TRL in diameter class 2; and 'Emphasis', 'Pelops', 'Exclamation' NG, and 'Ferro' were among the greatest. These patterns are the result of very high proportions of TRL falling within diameter classes 1 and 2 (>95\% in all rootstocks). Thus, as the proportion of TRL in diameter class 1 increases, the proportion in diameter class 2 decreases and vice versa. Proportions of diameter class 3 were lowest in 'Kazako', 'Exclamation' SG, and 'Pelops'; but, the proportions were very low $(<5 \%)$, indicating diameter class 3 described only a small portion of root systems. Proportions of diameter class lengths showed very little variation in response to harvest timing (Table 4). Comparisons of diameter class proportions by species reveal that bottle gourd rootstocks produced the lowest proportion of TRL in diameter class 1 , and all other rootstock species produced a greater proportion (Table 5 ). As with the analysis of rootstocks, an inverse relationship was observed between proportions of diameter classes 1 and 2 when comparing rootstock species.

SPECIFIC ROOT LENGTH. ANOVA of SRL determined the main effects of rootstock, species, and harvest date were significant, and no significant interactions of rootstock or species with harvest were observed. Thus, least square means for main effects were subjected to mean separation according to Tukey's HSD (Fig. 2). The greatest SRLs were observed in 'Kazako' and 'Exlamation' SG, and 'Pelops' produced the lowest SRL (Fig. 2A). However, when compared with 'Pelops', mean separation indicated the SRL of eight of the remaining 10 rootstocks were not significantly different. Thus, 9 of the 11 rootstocks produced similar SRLs, and 'Exclamation' SG and 'Kazako' rootstocks produced increased SRL. Comparisons of species revealed that watermelon and interspecific hybrid rootstocks

Table 3. Comparison of main effect of rootstock species on root system morphology characteristics of five cucurbit rootstock species with 'Exclamation' watermelon as the scion. Total root length, average root diameter, and root surface area were measured using intact harvested root systems and image analysis software (WinRHIZO version 2012b; Regent Instruments, Quebec, QC, Canada). Root weight-to-shoot weight ratios were calculated using the weight of dried root and shoot tissue of plants at each harvest date. ${ }^{\mathrm{z}}$

\begin{tabular}{|c|c|c|c|c|}
\hline Rootstock species $^{\mathrm{y}}$ & $\begin{array}{c}\text { Total root } \\
\text { length }(\mathrm{cm})^{\mathrm{x}}\end{array}$ & $\begin{array}{c}\text { Avg root } \\
\operatorname{diam}(\mathrm{mm})^{\mathrm{x}}\end{array}$ & $\begin{array}{l}\text { Root surface } \\
\text { area }\left(\mathrm{cm}^{2}\right)^{\mathrm{x}}\end{array}$ & $\begin{array}{c}\text { Root wt:shoot } \\
\text { wt (ratio) }\end{array}$ \\
\hline Pumpkin & $2,975 a^{w}$ & $0.1199 \mathrm{~b}$ & $320 \mathrm{a}$ & $0.4075 \mathrm{a}$ \\
\hline Squash & $2,916 \mathrm{a}$ & $0.1201 \mathrm{~b}$ & $318 \mathrm{a}$ & $0.3485 \mathrm{abc}$ \\
\hline $\begin{array}{l}\text { Interspecific hybrid } \\
\text { squash }\end{array}$ & $2,677 \mathrm{a}$ & $0.1078 \mathrm{~b}$ & 278 a & $0.3556 \mathrm{ab}$ \\
\hline Bottle gourd & $1,638 \mathrm{~b}$ & $0.1578 \mathrm{a}$ & $204 \mathrm{~b}$ & $0.3371 \mathrm{bc}$ \\
\hline Watermelon & $1,484 \mathrm{~b}$ & $0.1432 \mathrm{a}$ & $176 \mathrm{~b}$ & $0.2848 \mathrm{c}$ \\
\hline \multicolumn{5}{|l|}{ Effect ( $P$ value $)$} \\
\hline Species & $* * *$ & $* * *$ & $* * *$ & $* * *$ \\
\hline Harvest & $* * *$ & $* *$ & $* * *$ & $* * *$ \\
\hline Species $\times$ harvest & NS & NS & NS & NS \\
\hline
\end{tabular}

${ }^{\mathrm{z}}$ To account for heterogeneity of variance, analysis of variance and mean separation was conducted using square root transformed data for total root length then back-transformed for presentation in this table.

${ }^{\mathrm{y}}$ Interspecific hybrid squash derived from the cross Cucurbita maxima $\times$ C. moschata.

${ }^{\mathrm{x}} \mathrm{l} \mathrm{cm}=0.3937$ inch, $1 \mathrm{~mm}=0.0394$ inch, $1 \mathrm{~cm}^{2}=0.1550$ inch $^{2}$.

wean separation was achieved using the post hoc Tukey's honest significant difference multiple comparisons adjustment. Means followed by the same letter did not differ at $\alpha=0.05$.

NS, ${ }^{*},{ }^{*},{ }^{* *}$ Nonsignificant or significant at $P \leq 0.05,0.01$, or 0.001 , respectively.

Table 4. Comparison of main effects of rootstock and harvest date on root diameter class of 11 cucurbit rootstocks with 'Exclamation' watermelon as the scion. Root diameter class refers to the proportion of the total root length of each root system within one of three diameter classes and was measured using intact harvested root systems and image analysis software (WinRHIZO version 2012b; Regent Instruments, Quebec, QC, Canada). ${ }^{\mathrm{z}}$

\begin{tabular}{|c|c|c|c|}
\hline Rootstock & $\begin{array}{l}\text { Diameter class } \\
1(<0.5 \mathrm{~mm})^{\mathrm{y}}\end{array}$ & $\begin{array}{c}\text { Diameter class } \\
2(0.5-1.0 \mathrm{~mm})\end{array}$ & $\begin{array}{c}\text { Diameter class } \\
3(>1.0 \mathrm{~mm})\end{array}$ \\
\hline Kazako & $0.8704 \mathrm{a}^{\mathrm{x}}$ & $0.1064 \mathrm{e}$ & $0.0224 \mathrm{c}$ \\
\hline Exclamation SG & $0.8568 \mathrm{ab}$ & $0.1251 \mathrm{de}$ & $0.0171 \mathrm{c}$ \\
\hline Root Power & $0.8321 \mathrm{bc}$ & $0.1312 \mathrm{~cd}$ & $0.0358 \mathrm{ab}$ \\
\hline TZ148 & $0.8236 \mathrm{c}$ & $0.1397 \mathrm{~cd}$ & $0.0359 \mathrm{ab}$ \\
\hline RS841 & $0.8228 \mathrm{~cd}$ & $0.1407 \mathrm{~cd}$ & $0.0355 \mathrm{ab}$ \\
\hline Carnivor & $0.8173 \mathrm{cde}$ & $0.1456 \mathrm{bcd}$ & $0.0365 \mathrm{a}$ \\
\hline BSI & $0.8170 \mathrm{cde}$ & $0.1432 \mathrm{~cd}$ & $0.0390 \mathrm{a}$ \\
\hline Ferro & $0.8044 \mathrm{cde}$ & $0.1516 \mathrm{abc}$ & $0.0434 \mathrm{a}$ \\
\hline Exclamation NG & 0.8029 cde & $0.1698 \mathrm{ab}$ & $0.0432 \mathrm{a}$ \\
\hline Pelops & $0.7909 \mathrm{de}$ & $0.1707 \mathrm{a}$ & $0.0252 \mathrm{bc}$ \\
\hline Emphasis & $0.7858 \mathrm{e}$ & $0.1713 \mathrm{a}$ & $0.0368 \mathrm{a}$ \\
\hline \multicolumn{4}{|l|}{ Harvest } \\
\hline $1 \mathrm{WAT}$ & $0.8277 \mathrm{a}$ & 0.1446 & $0.0262 \mathrm{~b}$ \\
\hline 2 WAT & $0.8119 \mathrm{~b}$ & 0.1483 & $0.0383 \mathrm{a}$ \\
\hline 3 WAT & $0.8254 \mathrm{a}$ & 0.1389 & $0.0344 \mathrm{a}$ \\
\hline \multicolumn{4}{|l|}{ Effect ( $P$ value $)$} \\
\hline Rootstock & $* * *$ & $* * *$ & $* * *$ \\
\hline Harvest & $* *$ & NS & $* * *$ \\
\hline Rootstock $\times$ harvest & NS & NS & NS \\
\hline
\end{tabular}

${ }^{\mathrm{z}}$ Analysis of variance and mean separation were conducted using a logit transformation and a beta distribution for these proportion data.

${ }^{\mathrm{y}} 1 \mathrm{~mm}=0.0394$ inch

${ }^{\mathrm{x}}$ Mean separation was achieved using the post hoc Tukey's honest significant difference multiple comparisons adjustment. Means followed by the same letter did not differ at $\alpha=0.05$. Rootstock, harvest, and rootstock $\times$ harvest had 10,2 , and $20 \mathrm{df}$, respectively.

NS, ${ }^{*}, * * * *$ Nonsignificant or significant at $P \leq 0.05,0.01$, or 0.001 , respectively.

$\mathrm{NG}=$ nongrafted; $\mathrm{SG}=$ self-grafted; WAT $=$ week $(\mathrm{s})$ after transplanting.

produced the greatest SRL, squash and pumpkin produced an intermediate SRL, and bottle gourd rootstocks produced the lowest SRL (Fig. 2B). SRL increased as harvest was delayed from 1 to 2 WAT, but did not 
change between harvest at 2 and 3

WAT (Fig. 2C).

\section{Discussion}

Previous research has used WinRHIZO software to characterize root systems of crops such as corn (Zea mays), rice (Oryza sativa), sweet potato (Ipomoea batatas), and tomato, and stolons of bermudagrass (Cynodon dactylon) (Pace et al., 2014; Pornaro et al., 2017; Sandhu et al., 2016; Suchoff et al., 2017; Wijewardana et al., 2018). This study represents the first attempt to characterize root system morphology of commercially

Table 5. Comparison of main effect of rootstock species date on root diameter class of five cucurbit rootstock species with 'Exclamation' watermelon as the scion. Root diameter class refers to the proportion of the total root length of each root system within one of three diameter classes and was measured using intact harvested root systems and image analysis software (WinRHIZO version $2012 \mathrm{~b}$; Regent Instruments, Quebec, QC, Canada). ${ }^{\mathrm{z}}$

\begin{tabular}{lccc}
\hline Rootstock species $^{\mathbf{y}}$ & $\begin{array}{c}\text { Diameter class } \\
\mathbf{1}(<\mathbf{0 . 5} \mathbf{~ m m})^{\mathbf{x}}\end{array}$ & $\begin{array}{c}\text { Diameter class } \\
\mathbf{2}(\mathbf{0 . 5}-\mathbf{1 . 0} \mathbf{~ m m})\end{array}$ & $\begin{array}{c}\text { Diameter class } \\
\mathbf{3}(>\mathbf{1 . 0} \mathbf{~ m m})\end{array}$ \\
\hline Interspecific hybrid squash & $0.8336 \mathrm{a}^{\mathrm{w}}$ & $0.1331 \mathrm{c}$ & $0.0327 \mathrm{~b}$ \\
Watermelon & $0.8273 \mathrm{a}$ & $0.1501 \mathrm{~b}$ & $0.0215 \mathrm{c}$ \\
Pumpkin & $0.8173 \mathrm{a}$ & $0.1422 \mathrm{bc}$ & $0.0400 \mathrm{a}$ \\
Squash & $0.8170 \mathrm{a}$ & $0.1432 \mathrm{bc}$ & $0.0390 \mathrm{ab}$ \\
Bottle gourd & $0.7885 \mathrm{~b}$ & $0.1704 \mathrm{a}$ & $0.0402 \mathrm{a}$ \\
Effect $(P$ value $)$ & $* * *$ & & $* * *$ \\
$\quad$ Species & $* *$ & NS & $* * *$ \\
Harvest & NS & NS & NS \\
\hline
\end{tabular}

${ }^{\mathrm{z}}$ Analysis of variance and mean separation was conducted using square root-transformed data when appropriate, which was then back-transformed for this table.

${ }^{y}$ Interspecific hybrid squash derived from the cross Cucurbita maxima $\times$ C. moschata.

${ }^{\mathrm{x}} \mathrm{l} \mathrm{mm}=0.0394$ inch.

${ }^{\text {w}}$ Mean separation was achieved using the post hoc Tukey's honest significant difference multiple comparisons adjustment. Means followed by the same letter did not differ at $\alpha=0.05$.

Ns, ${ }^{*},{ }^{* *},{ }^{* *}$ Nonsignificant or significant at $P \leq 0.05,0.01$, or 0.001 , respectively

available cucurbit rootstocks grown in a solid, soilless substrate. Miller et al. (2013) compared root system architecture of field-grown grafted and SG watermelon at different irrigation regimes. They found no difference among the root length distribution among grafted treatments and discovered that the majority of roots were within the first 12 inches of the soil profile. Unfortunately, no further data regarding root morphology such as average diameter or diameter class proportions were given. Although these authors did not find yield differences among the grafted treatments, other researchers have shown that certain rootstocks can improve abiotic stress tolerance as well as nutrient and water use efficiency (Pulgar et al., 2000; Rouphael et al., 2008).

Although our study did not compare root system morphology as it relates to resource availability, our results may help explain some of the improved nutrient and resource acquisition observed by researchers using grafted watermelon (Rouphael et al., 2008). Pulgar et al. (2000) found that nitrogen uptake was improved when grafting watermelon onto squash rootstocks. 'BSI' was
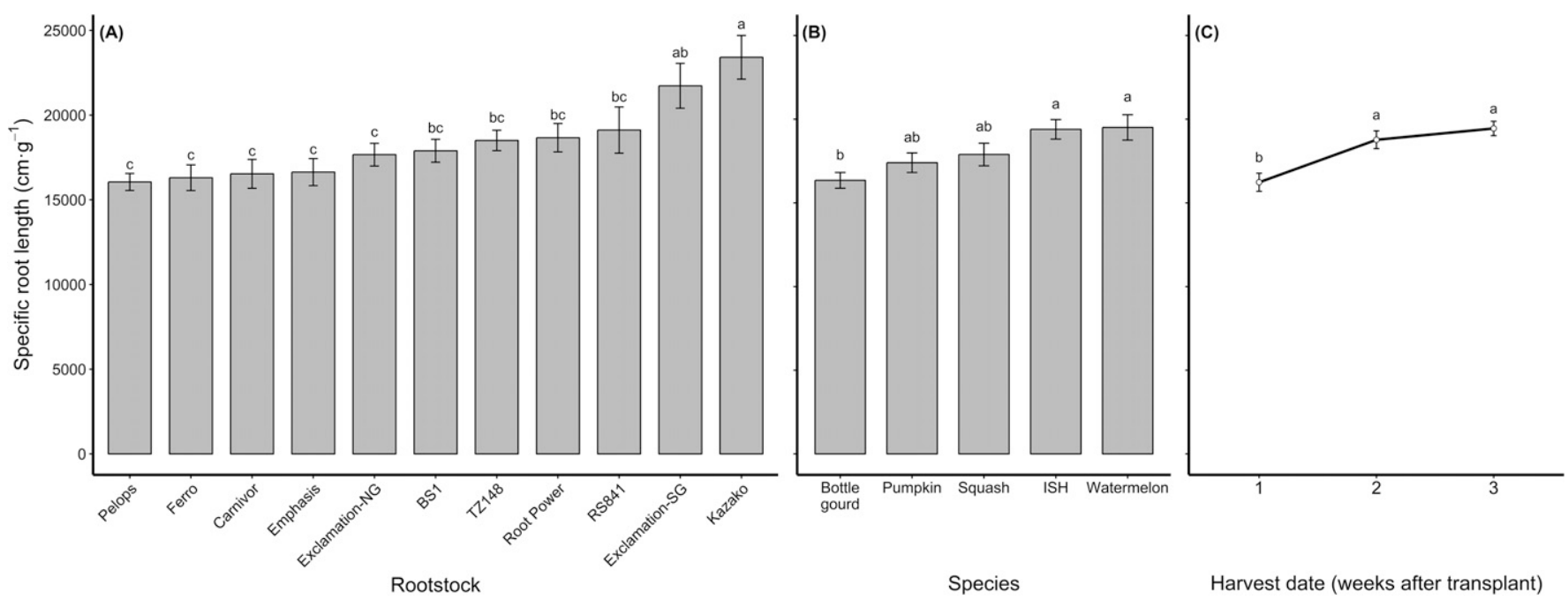

Fig. 2. Comparison of specific root length ( \pm SE) as affected by (A) rootstock, (B) species, and (C) harvest date. 'Exclamation' watermelon was grafted to 10 cucurbit rootstocks and was used as a nongrafted control. All plants were grown in a greenhouse and harvested at 1, 2, and 3 weeks after transplanting. Specific root length was measured using intact harvested root systems and image analysis software (WinRHIZO version 2012b; Regent Instruments, Quebec, QC, Canada). Analysis of variance (ANOVA) and mean separation were conducted on square root-transformed data because of heterogeneity of variance, and data were subsequently back-transformed for presentation in this figure. ANOVA determined Pvalues were $<0.0001,<0.0001$, and 0.0010 for rootstock, species, and harvest date, respectively. No significant interactions were observed. Mean separation was achieved using the post hoc Tukey's honestly significant difference multiple comparisons adjustment. Means accompanied by the same letter did not differ at $\alpha=0.05$. SG, self-grafted; NG, nongrafted; ISH, interspecific hybrid squash derived from the cross Cucurbita maxima $\times$ C. moschata; $1 \mathrm{~cm} \cdot \mathrm{g}^{-1}=11.1612$ inches $/ \mathrm{oz}$. 
the only squash rootstock characterized; however, significant differences exist when comparing 'BSl' with 'Exclamation'. TRL was $\approx 80 \%$ longer in 'BSI' compared with 'Exclamation' NG and SG (Table 2). Furthermore, the average root diameter of 'BSI' was smaller than 'Emphasis' NG and SG, but also had a greater total surface area. Nitrogen is mobile within the soil profile and, consequently, bulk flow-not specific root system characteristics-is most important for nitrogen uptake (Hill et al., 2006). However, a root system with smaller diameter, longer roots that has a greater total surface area could allow for improved interception of the nitrogen-containing soil solution. As such, those results observed by Pulgar et al. (2000) may be the result of the increased surface area and consequent interception of soil solution when using squash as a rootstock.

Results from the current study reveal the relationships among common measurements to describe root system morphology. For example, 'Pelops', 'Emphasis', and 'Exclamation' NG were among those with the lowest TRL, greatest average root diameter, and lowest proportion diameter class 1 (Tables 1 and 2). Along with 'Kazako', these rootstocks had the lowest root surface areas and root: shoot ratios (Table 2). Most importantly, this study demonstrates the wide range of root system morphologies represented among this diverse selection of cucurbit rootstocks. The current study can only describe the morphologic characteristics of root systems at 1, 2, and 3 WAT, and cannot predict performance in field settings. However, the disparity in root systems and reported morphologic characteristics of rootstocks and rootstock species indicates that a wide range of root systems are available for watermelon grafting. Future research using this protocol could investigate rootstocks for relative plasticity of root system morphologies in response to varying levels of environmental stresses, such as shade, suboptimal temperatures, or nutrient deprivation. Complementary research describing the relationship between root system morphology and performance of grafted plants in the field would provide a deeper understanding of which morphologic traits are associated with and responsible for particular stress tolerance or disease resistance.

\section{Literature cited}

Ahn, S.J., Y.J. Im, G.C. Chung, B.H. Cho, and S.R. Suh. 1999. Physiological responses of grafted cucumber leaves and rootstock roots affected by low root temperature. Scientia Hort. 81: 397-408.

Cohen, R., J. Tyutyunik, E. Fallik, Y. Oka, Y. Tadmor, and M. Edelstein. 2014. Phytopathological evaluation of exotic watermelon germplasm as a basis for rootstock breeding. Scientia Hort. 165: 203-210.

Colla, G., Y. Roupahel, M. Cardarelli, and E. Rea. 2006. Effect of salinity on yield, fruit quality, leaf gas exchange, and mineral composition of grafted watermelon plants. HortScience 41:622-627.

Comas, L., S. Becker, V. Cruz, P. Byrne, and D. Dierig. 2013. Root traits contributing to plant productivity under drought. Front. Plant Sci. 4:442.

Daley, S. and R. Hassell. 2014. Fatty alcohol application to control meristematic regrowth in bottle gourd and interspecific hybrid squash rootstocks used for grafting watermelon. HortScience 49:260-264.

Hassell, R.L., F. Memmott, and D.G. Liere. 2008. Grafting methods for watermelon production. HortScience 43: 1677-1679.

Hill, J.O., R.J. Simpson, A.D. Moore, and D.F. Chapman. 2006. Morphology and response of roots of pasture species to phosphorus and nitrogen nutrition. Plant Soil 286:7-19.

Ho, M., J. Rosas, K. Brown, and J. Lynch. 2005. Root architectural tradeoffs for water and phosphorus acquisition. Funct. Plant Biol. 32:737-748.

Huang, Y., Z. Bie, S. He, B. Hua, A. Zhen, and Z. Liu. 2010. Improving cucumber tolerance to major nutrients induced salinity by grafting onto Cucurbita ficifolia. Environ. Expt. Bot. 69:32-38.

Keinath, A.P. and R.L. Hassell. 2014. Suppression of fusarium wilt caused by Fusarium oxysporum f. sp. niveum race 2 on grafted triploid watermelon. Plant Dis. 98:1326-1332.

Lee, J. and M. Oda. 2003. Grafting of herbaceous vegetable and ornamental crops. Hort. Rev. 28:61-124.

Lee, S.H., S. Ahn, Y.J. Im, K. Cho, B. Cho, G. Chung, and O. Han. 2005a. Differential impact of low temperature on fatty acid unsaturation and lipoxygenase activity in figleaf gourd and cucumber roots. Biochem. Biophys. Res. Commun. 330:1194-1198.

Lee, S.H., G. Chung, and E. Steudle. $2005 \mathrm{~b}$. Gating of aquaporins by low temperature in roots of chilling-sensitive cucumber and chilling-tolerant figleaf gourd. J. Expt. Bot. 56:985-995.

Louws, F.J., C.L. Rivard, and C. Kubota. 2010. Grafting fruiting vegetables to manage soilborne pathogens, foliar pathogens, arthropods and weeds. Scientia Hort. 127:127-146.

Lovelli, S., A. Scopa, M. Perniola, T. Di Tommaso, and A. Sofo. 2012. Abscisic acid root and leaf concentration in relation to biomass partitioning in salinized tomato plants. J. Plant Physiol. 169:226233.

Manavalan, L.P., S.K. Guttikonda, V.T. Nguyen, J.G. Shannon, and H.T. Nguyen. 2010. Evaluation of diverse soybean germplasm for root growth and architecture. Plant Soil 330:503-514.

Maynard, D.M. 1989. Triploid watermelon seed orientation affects seedcoat adherence on emerged cotyledons. HortScience 24:603-604.

Mickelbart, M.V., P.M. Hasegawa, and J. Bailey-Serres. 2015. Genetic mechanisms of abiotic stress tolerance that translate to crop yield stability. Nat. Rev. Genet. 16:237-251.

Miller, G., A. Khalilian, J.W. Adelberg, H. J. Farahani, R.L. Hassell, and C.E. Wells. 2013. Grafted watermelon root length density and distribution under different soil moisture treatments. HortScience 48:1021-1026.

Pace, J., N. Lee, H. Naik, B. Ganapathysubramanian, and T. Lubberstedt. 2014. Analysis of maize (Zea mays L.) seedling roots with the high-throughput image analysis tool ARIA (automatic root image analysis). PLoS One 9:e108255.

Petrie, C. and A. Hall. 1992. Water relations in cowpea and pearl millet under soil water deficits: I. Contrasting leaf water relations. Austral. J. Plant Physiol. 19:577-589.

Pornaro, C., S. Macolino, A. Menegon, and M. Richardson. 2017. WinRHIZO technology for measuring morphological traits of bermudagrass stolons. Agron. J. 109:3007-3010.

Pulgar, G., G. Villora, D.A. Moreno, and L. Romero. 2000. Improving the mineral nutrition in grafted watermelon plants: Nitrogen metabolism. Biol. Plant. 43: 607-609.

Rouphael, Y., M. Cardarelli, G. Colla, and E. Rea. 2008. Yield, mineral composition, water relations, and water use efficiency of 


\section{Research Reports}

grafted mini-watermelon plants under deficit irrigation. HortScience 43:730 736.

Rouphael, Y., J.H. Venema, M. Edelstein, D. Savvas, G. Colla, G. Ntatsi, M. BenHur, P. Kumar, and D. Schwarz. 2017. Grafting as a tool for tolerance of abiotic stress, p. 171-215. In: G. Colla, F. PérezAlfocea, and D. Schwarz (eds.). Vegetable grafting: Principles and practices. $\mathrm{CAB}$ International, Wallingford, UK.

Sandhu, N., K. Raman, R. Torres, A. Audebert, A. Dardou, A. Kumar, and A. Henry. 2016. Rice root architectural plasticity traits and genetic regions for adaptability to variable cultivation and stress conditions. Plant Physiol. 171: 2562-2576.

Schwarz, D., Y. Rouphael, G. Colla, and J.H. Venema. 2010. Grafting as a tool to improve tolerance of vegetables to abiotic stresses: Thermal stress, water stress and organic pollutants. Scientia Hort. 127: 162-171.

Suchoff, D.H., C.C. Gunter, and F.J. Louws. 2017. Comparative analysis of root system morphology in tomato rootstocks. HortTechnology 27:319-324.
Wijewardana, C., K.R. Reddy, M.W. Shankle, S. Meyers, and W. Gao. 2018. Low and high-temperature effects on sweetpotato storage root initiation and early transplant establishment. Scientia Hort. 240:38-48.

Zhou, Y., L. Huang, Y. Zhang, K. Shi, J. $\mathrm{Yu}$, and S. Nogues. 2007. Chill-induced decrease in capacity of RuBP carboxylation and associated $\mathrm{H}_{2} \mathrm{O}_{2}$ accumulation in cucumber leaves are alleviated by grafting onto figleaf gourd. Ann. Bot. 100:839848 .

Zobel, R.W., T.B. Kinraide, and V.C. Baligar. 2007. Fine root diameters can change in response to changes in nutrient concentrations. Plant Soil 297:243-254. 